\title{
CONGRESSIONAL STANDING TO CHALLENGE EXECUTIVE ACTION
}

The past few years have seen the development of a new political weapon available to Congress in its efforts to curb the growing power of the executive branch of the federal government: the use of the federal courts to have executive action declared illegal. The plaintiffs in these suits are individual congressmen, suing in their official capacities and bringing their high political visibility into the courtroom. The goal of the lawsuits, the restoration of a proper constitutional and political balance between the legislative and executive branches of government, is one which the plaintiff congressmen have been unable to achieve through normal legislative means.

In none of these suits have the congressmen alleged that the executive acts have injured them personally in any manner. Rather, the legislators have claimed injury as members of Congress. Thus, the suits are brought by congressmen qua congressmen. As a result, there would seem to be serious questions regarding their standing to sue in the federal courts to have the executive action declared illegal. ${ }^{1}$ The courts addressing the question have not reached uniform results.

This Comment will examine four such cases brought by congressmen challenging executive action. ${ }^{2}$ Following a short summary of the four decisions, congressional standing will be

1 There is precedent for the proposition that suits brought by legislators qua legislators are cognizable. In Coleman v. Miller, 307 U.S. 433 (1939), state legislators brought suit for a declaration that the lieutenant governor had illegally broken a tie vote in the state senate, in favor of ratification of a constitutional amendment. The Supreme Court found that the plaintiffs had a sufficiently "plain, direct and adequate interest in maintaining the effectiveness of their votes" to give them standing to challenge the ratifying procedure as unconstitutional under the article $\mathrm{V}$ amendment procedure. Id. at 438.

It must be noted, however, that Coleman is distinguishable from cases brought by congressmen in federal courts because it involved state legislators, and thus avoids some of the problems of separation of powers inherent in federal suits.

${ }^{2}$ Holtzman v. Schlesinger, 484 F.2d 1307 (2d Cir.), cert. denied, 94 S. Ct. 1935 (1974), rev'g Holtzman v. Richardson, 361 F. Supp. 544 (E.D.N.Y. 1973); Mitchell v. Laird, 476 F.2d 533 (D.C. Cir. 1973); Nader v. Bork, 366 F. Supp. 104 (D.D.C. 1973), appeal docketed, No. 74-1260, D.C. Cir., Feb. 20, 1974; Kennedy v. Sampson, 364 F. Supp. 1075 (D.D.C. 1973), aff'd, No. 73-2121, D.C. Cir., Oct. 29, 1973. An earlier decision, Gravel v. Laird, 347 F. Supp. 7 (D.D.C. 1972), rejected congressional standing to challenge the legality of the Vietnam War without discussion of the interest of congressmen qua congressmen in maintaining the suit. The decision has been effectively 
analyzed in light of the latest Supreme Court standing requirements. ${ }^{3}$ This analysis will then be applied to the four cases. Finally, a different basis for congressional standing will be offered, one admittedly not in accord with current standing doctrine.

In three of the four challenges to executive action brought by congressmen in their official capacities, standing was granted. The first case was Mitchell $v$. Laird, ${ }^{4}$ in which Parren Mitchell and twelve other congressmen alleged that the executive branch had engaged in war in Indochina without Congressional approval. The plaintiff congressmen argued that this act violated their constitutional right "to decide whether the United States should fight a war." In the second suit, Kennedy v. Sampson, ${ }^{6}$ Senator Edward Kennedy challenged the attempted pocket veto of the Family Practice of Medicine $\mathrm{Act}^{7}$ during a congressional recess. He claimed that he had been injured in his official capacity as a member of Congress in that the President's action had "deprived him of his constitutional right to vote to override the Presidential Veto ...." ${ }^{8}$ The plaintiffs in the third suit, Nader $v$. Bork, ${ }^{9}$ were three congressmen and Ralph Nader. ${ }^{10}$ They sought a declaratory judgment that Watergate Special Prosecutor Archibald Cox had been illegally

overruled by the Court of Appeals for the District of Columbia Circuit in Mitchell v. Laird, 476 F.2d 533 (D.C. Cir. 1973), and will not be discussed in this Comment.

No attempt is made in this Comment to take account of problems of congressional standing with regard to suits against the legislative branch, administrative agencies, or private parties. In each such situation, many of the same issues which arise in congressional suits against the executive-e.g., the need for injury in fact and proper nexus between status as congressman and action challenged-may be found. Nonetheless, different problems-such as separation of powers-arise in suits challenging executive action, and this Comment is confined to those issues.

Other possible problems in these suits, such as $\S 1331$ "arising under" jurisdiction, unconsented suit against the United States, the "political question" basis for declining jurisdiction, and the $\$ 10,000$ in controversy jurisdictional requirement, are outside the scope of this Comment.

${ }^{3}$ See, e.g., Sierra Club v. Morton, 405 U.S. 727 (1972); Association of Data Processing Service Organizations v. Camp, 397 U.S. 150 (1970); Flast v. Cohen, 392 U.S. 83 (1968); Baker v. Carr, 369 U.S. 186 (1962).

476 F.2d 533 (D.C. Cir. 1973).

${ }^{5} I d$. at 535. See U.S. Const. art. I, $\$ 8$ ("The Congress shall have [p]ower . . [t]o declare [w]ar ....").

6364 F. Supp. 1075 (D.D.C. 1973), aff'd, No. 73-2121, D.C. Cir., Aug. 14, 1974.

${ }^{7}$ S. 3418, 91 st Cong., 2d Sess. (1970).

${ }^{8} 364$ F. Supp. at 1078. See U.S. Consr. art. I, $\$ 7$ (congressional override of veto).

9366 F. Supp. 104, appeal docketed, No. 74-1260, D.C. Cir., Feb. 20, 1974.

${ }^{10}$ Nader was dismissed as a plaintiff for lack of standing. Id. at $106 \mathrm{n} .1$. The three congressional plaintiffs were Senator Frank Moss, Representative Bella Abzug, and Representative Jerome Waldie. 
discharged. The district court opinion does not state what injury they alleged. ${ }^{11}$

The injuries alleged in these cases make it clear that the plaintiffs were bringing suit in their official, not their individual, capacities. The ground adopted by the Mitchell and Nader courts for granting standing was that congressmen have an independent duty to investigate grounds for impeachment of the President, should the executive acts in issue be declared illegal, and to vote on bills and appropriations. The persuasiveness of this rationale is open to question. ${ }^{12}$ The Kennedy court granted standing on the basis of both the impeachment rationale and the more supportable argument that the plaintiff had been deprived of his right to vote to override the veto. ${ }^{13}$

Though Coongresswoman Elizabeth Holtzman also alleged injury in her official capacity, she was denied standing in the fourth major case, Holtzman v. Schlesinger. ${ }^{14}$. She alleged that the President and his military subordinates were engaging in "intensive combat operations in Cambodia and elsewhere in Indochina in the absence of Congressional authorization," thus usurping Congress' war-making power. ${ }^{15}$ Nonetheless, the Court of Appeals for the Second Circuit rejected the two rationales advanced by the other three courts for granting standing, denying that Holtzman had been deprived of any right to vote and finding no relevance in impeachment proceedings. ${ }^{16}$

The rationales adopted by the courts to buttress their conclusions rely heavily on recent Supreme Court cases discussing the standing doctrine. While none of these Supreme Court decisions speak directly to the propriety of allowing members of the legislative branch to seek judicial relief from action taken by members of the executive branch, an examination of the

${ }^{11}$ The plaintiffs apparently alleged injury to the performance of their congressional duties, since the court discussed only their right to sue in their official capacity.

${ }^{12}$ See notes 45-50, 57-64 infra.

${ }^{13}$ See notes 53-56 infra.

${ }^{14} 484$ F.2d 1307 (2d Cir.), cert. denied, 94 S. Ct. 1935 (1974), rev'g Holtzman v. Richardson, 361 F. Supp. 544 (E.D.N.Y. 1973).

15361 F. Supp. at 549. See note 5 supra. Congresswoman Holtzman brought suit individually as well as in her capacity as a member of the House of Representatives. Neither the district court nor the court of appeals discussed her ability to sue as an individual. It is difficult to determine on what basis she could gain standing to sue in her individual capacity. One possibility, suing as a taxpayer, has been rejected by most courts as a basis for allowing standing to challenge executive war policies. See, e.g., Velvel v. Nixon, 415 F.2d 236 (10th Cir. 1969), cert. denied, 396 U.S. 1042 (1970). Cf. Flast v. Cohen, 392 U.S. 83 (1968).

${ }^{16} 484 \mathrm{~F} .2 \mathrm{~d}$ at 1315 . The court stated that an opinion based upon possible impeachment proceedings would be an advisory opinion. Id. 
leading cases will aid in determining the proper resolution of the standing problem.

\section{The Law of Standing}

Proféssor Davis has decribed the law of standing as a "mass of confused logic-chopping about bewildering technicalities."17 While it is unnecessary here to detail the history of the standing doctrine in the Supreme Court, ${ }^{18}$ a brief discussion of standing in general will be helpful in applying the leading cases to the more recent lower court decisions involving congressional standing.

"The first point of reference in determining the parameters of standing is Article III, Section 2 of the Constitution," 19 which vests jurisdiction in the federal courts over all "cases" and "controversies" arising under the Constitution and laws of the United States. However, the standing rules developed by the Supreme Court seem more narrowly confined than the "case" or "controversy" requirement would permit. ${ }^{20}$

Nonetheless, the Supreme Court has tended to use standing as a means of assuring article III jurisdiction. In Baker $v$. $\mathrm{Carr},{ }^{21}$ the test was formulated as follows:

Have the appellants alleged such a personal stake in the outcome of the controversy as to assure that concrete adverseness which sharpens the presentation of issues upon which the court so largely depends for illumination of difficult constitutional questions? This is the gist of the question of standing. ${ }^{22}$

${ }^{17}$ Davis, Standing: Taxpayers and Others, 35 U. CHI. L. REv. 601, 628 (1968). Justice Douglas has concluded that "[g]eneralizations about standing to sue are largely worthless as such." Association of Data Processing Service Organizations v. Camp, 397 U.S. I50, 151 (1970). Similarly, Justice Frankfurter found standing so "complicated" that he declined to set out the "divergent grounds" of the various Justices supporting standing in United States $e x$ rel. Chapman v. FPC, 345 U.S. 153, 156 (1953).

${ }^{18}$ For a review of the history of the standing doctrine, see, e.g., Flast v. Cohen, 392 U.S. 83 (1968); Scott, Standing in the Supreme Court-A Functional Analysis, 86 HARv. L. Rev. 645 (1973). Judge Arlin Adams has set forth what is probably the most exhaustive summary of the standing cases. Richardson v. United States, 465 F.2d 844, 857 (3d Cir. 1972) (Adams, J., dissenting).

19 Richardson v. United States, 465 F.2d 844, 857 (3d Cir. 1972) (Adams, J., dissenting).

${ }^{20}$ In Sierra Club v. Morton, 405 U.S. 727, 732 n.3 (1972), Justice Stewart, writing for the Court, implied that standing is not a constitutional requirement. "[W] dispute is otherwise justiciable, the question whether the litigant is a "proper party to request an adjudication of a particular issue' ... is one within the power of Congress to determine." See also Berger, Standing to Sue in Public Actions: Is it a Constitutional Requirement?, 78 Yale L. J. 816 (1968); Jaffe, Standing Again, 84 HARv, L. REv. 633 (1971).

21369 U.S. 186 (1962).

22 Id. at 204. 
This test was reiterated by the Court in Flast v. Cohen, ${ }^{23}$ in which the Court stated that "in terms of Article III limitations on federal court jurisdiction, the question of standing is related only to whether the dispute sought to be adjudicated will be presented in an adversary context and in a form historically viewed as capable of judicial resolution." ${ }^{24}$ In Flast the Court established a two-prong test for determining when a taxpayer could bring a suit to challenge a government spending program. This test is useful for determining when standing will be granted to parties such as congressmen, who, like the taxpayers in Flast, can claim little personal injury from the action being challenged. The test was formulated in the following terms:

The nexus demanded of federal taxpayers has two aspects to it. First, the taxpayer must establish a logical link between that status and the type of legislative enactment attacked. ... Secondly, the taxpayer must establish a nexus between that status and the precise nature of the constitutional infringement alleged. ${ }^{25}$

The Supreme Court restated the dual nature of the standing requirement, in an entirely different context, in Association of.Data Processing Service Organizations v. Camp. ${ }^{26}$ It and a companion case $^{27}$ considered standing for private parties to challenge administrative action. Data Processing required, first, that plaintiffs have suffered some "injury in fact, economic or otherwise,"28 and, second, that they be "arguably within the zone of interests to be protected or regulated by the statute or constitutional guarantee in question." 29 This two-prong test is essentially the test formulated in Flast, reshaped to apply more generally to parties suing as individual plaintiffs rather than as litigants claiming a particular status, such as that of taxpayer. ${ }^{30}$

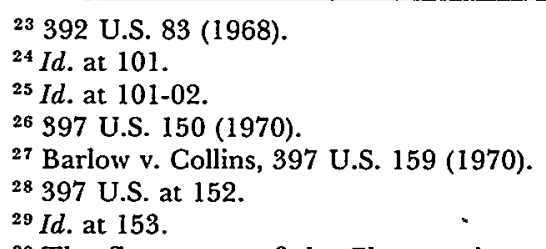

${ }^{30}$ The first nexus of the Flast test is really a requirement of an allegation of injury in fact. Thus, a taxpayer qua taxpayer has no standing to attack an appropriation which is merely incidental to the "administration of an essentially regulatory statute." Flast v. Cohen, 392 U.S. 83, 102 (1968). This lack of standing results from the inability of the taxpayer to demonstrate that he has suffered any injury-even if only a trifling one-other than that "he suffers in some indefinite way in common with people generally." Frothingham v. Mellon, 262 U.S. 447, 488 (1923).

Similarly, the second prong of the Flast test is identical to the second step of the Data Processing test. Thus, Flast requires that the plaintiff taxpayer be within the zone 
In the most recent of its pronouncements on standing, Sierra Club v. Morton, ${ }^{31}$ the Court reemphasized the importance of "injury in fact" as a requirement for standing. The Court made clear that one suing on behalf of the public interest lacks standing unless he is able to claim some personal injury. Taken together with Flast, Sierra Club establishes that a trifling personal injury is both sufficient and necessary to satisfy the first step of the standing test. ${ }^{32}$

\section{A Test for Congressional Standing}

Applying these cases to the issue at hand, one can formulate a test to determine when a congressman suing in his official capacity has standing to challenge executive action. First, he must allege that the executive action directly implicates his duties as a congressman. In Flast terms, this means that he must establish a nexus between his status as a congressman and the executive action attacked; in Sierra Club terms, he must allege "injury in fact" to the performance of his job as a congressman. Second, the congressman must establish a direct connection between his status as congressman and the constitutional provision alleged to have been breached by the executive action. This satisfies both the second nexus of Flast (between his status and the nature of the alleged constitutional infringement) and the more generalized Data Processing requirement that the plaintiff be arguably within the zone of interests to be protected by the constitutional or statutory provision.

The utility of this test can be seen more clearly by positing three hypothetical executive acts. In the first, the President appoints a federal judge without the necessary advice and consent of the Senate. ${ }^{33}$ Any senator should have standing to challenge the legality of the appointment, since he will have suffered injury in the performance of his job through the inability to uti-

of interests to be protected by the constitutional guarantee alleged to have been infringed by the taxing measure. The constitutional provision must therefore be one intended to protect taxpayers. For example, in Flast the constitutional provision allegedly violated was the first amendment guarantee against the establishment of religion, one historically considered to protect against government taxing measures designed to benefit religion. See 392 U.S. at 103-04 (quoting 2 WRITINGs of James Madison 183, 186 (G. Hunt ed. 1901): "'[T] he same authority which can force a citizen to contribute three pence only of his property for the support of any one establishment, may force him to conform to any other establishment in all cases whatsoever:" ")

${ }^{31} 405$ U.S. 727 (1972).

${ }^{32}$ See The Supreme Court: 1971 Term, 86 Harv. L. Rev. 50, 234, 239 (1972); Davis, supra note 17 , at 613 . Professor Davis hypothesizes that the injury suffered by the taxpayers in Flast may have amounted to no more than twelve cents. Id. at 611 .

${ }^{33}$ U.S. ConST. art. II, $\$ 2$. 
lize his constitutionally-mandated power to approve or disapprove the appointment. Furthermore, he will be able to establish the necessary nexus between his status as a senator and the constitutional provision alleged to have been breached by the appointment, since the constitutional advise and consent provision was designed to assure senatorial input into the appointment procedure. Under this analysis, however, no member of the House of Representatives would have standing.

As a second example, one can hypothesize a patently invalid regulation promulgated by the Secretary of Transportation barring any black person from traveling between states. No congressman would have standing under the test to challenge this executive act. While the congressman might establish the necessary first nexus between his role as congressman and the action taken (for example, an allegation that the rule exceeds the scope of authority delegated by Congress to the Secretary), he would be unable to show that he is within the zone of interests to be protected by the fifth amendment due process clause, which prohibits racial discrimination by the federal government.

In a third hypothetical situation, the President appoints a commission to examine the personal lives of all leading newsmen who have criticized him. Since it would be impossible for any congressman to demonstrate injury to his duties, he would have no standing to challenge the legality of the order.

The two-step test developed in Flast, Data Processing, and Sierra Club would thus separate cases in which a genuine congressional interest may be found from those in which a congressman may be concerned with vindicating the public interest but in which his congressional status is not involved. It therefore assures that access to the judicial process will be limited to situations in which legislative concerns are sufficiently paramount to warrant interference with executive action. It similarly guarantees that in situations involving purely discretionary actions taken by the executive branch, only those parties directly affected by the action will be able to resort to the courts for redress. In short, it reflects the very purpose of the standing doctrine: to "assure that concrete adverseness which sharpens the presentation of issues upon which the court so largely depends."34

It could be contended that congressmen should never be able to bring a lawsuit in their official capacity challenging executive action. The argument would stress that it is an imper-

${ }^{34}$ Baker v. Carr, 369 U.S. 186, 204 (1962). But see section IV infra. 
missible intrusion of the judiciary into the affairs of the coordinate branches of government to allow a federal court to enjoin or declare illegal executive action at the behest of a single member of Congress. The Constitution distributes powers among the three branches; it is an unconstitutional violation of the separation of powers, the argument runs, for the judiciary so to meddle in a squabble between the legislature and the executive. ${ }^{35}$ Furthermore, the courts must be particularly wary of intervention because theirs is the only branch not directly responsible to the people. It is antimajoritarian and undemocratic in principle to allow life-tenured judges to grant relief to congressmen who in many cases have been unable or unwilling to persuade a majority of their congressional colleagues of the rectitude of their position. ${ }^{36}$

This argument has some force but loses its validity when it is posited that the executive action exceeds constitutional and statutory authority and encroaches on legislative rights. Article III extends judicial power to all cases and controversies arising under the Constitution and laws of the United States, and at least since Marbury v. Madison ${ }^{37}$ it has been clear that it is within the judicial power to declare illegal acts of a co-equal branch of government performed without constitutional authority. In fact, in Marbury, Chief Justice Marshall professed the view that "the very essence of civil liberty certainly consists in the right of every individual to claim the protection of the laws, whenever he receives an injury." 38 That the individual is a member of the legislative branch ${ }^{39}$ and that the "injury" is the unlawful impairment of the ability to fulfill legislative duties effectively should not deprive the congressman of his right to judicial intervention, even conceding that his position may not comport with that of a majority of his fellow legislators. ${ }^{\mathbf{4 0}}$

${ }^{35}$ A similar argument, contending that taxpayer suits were not permissible, was made on behalf of the government and rejected by the Court in Flast v. Cohen, 392 U.S. 83, 98 (1968).

${ }^{36}$ But see Jaffe, The Citizen as Litigant in Public Actions: the Non-Hohfeldian or Ideological Plaintiff, 116 U. PA. L. REv. 1033, 1038-39 (1968).

${ }^{37} 5$ U.S. (1 Cranch) 137 (1803).

${ }^{38} I d$. at 162 (dictum).

${ }^{39}$ Concern for the proper allocation of powers among the branches of government can best be accounted for through the other doctrines which comprise the notion of justiciability-e.g., political question, ripeness, and sovereign immunity. See Davis, supra note 17, at 635 ("The law of standing is unsuited to assuring that issues will be appropriate for judicial determination and properly presented."); Davis, The Liberalized Law of Standing, 37 U. CHI. L. REv. 450, 469 (1970). See also Jaffe, supra note 36, at 1042 .

${ }^{40}$ In Coleman v. Miller, 307 U.S. 433 (1939), which held that standing should be granted state legislators who challenged the procedure used to ratify a constitu- 
To reiterate, then, a congressman should have standing to challenge executive action under current Supreme Court standing doctrine if he alleges "injury" to the effective performance of his job as congressman and if the constitutional or statutory provision allegedly breached by the executive was intended to give Congress rights which are threatened by the executive action.

\section{Applying the Test for Congressional STANDING to THE CASES}

When this test for determining congressional standing to challenge executive action is applied to the actual cases which have arisen thus far, it becomes apparent that the courts have proceeded without formulating clear and consistent standards. The failure to consider the issue of congressional standing in a well-reasoned manner can be seen by examining in more detail the four cases discussed earlier. ${ }^{41}$

The two congressional "stop the war" cases came to different conclusions on the standing question. In Mitchell $v$. Laird, ${ }^{42}$ the Court of Appeals for the District of Columbia Circuit held that congressmen had standing to challenge executive action taken in prosecuting the war in Indochina without congressional approval. In Holtzman v. Schlesinger, ${ }^{43}$ however, the Court of Appeals for the Second Circuit concluded that there was no congressional standing to test the legality of bombing and other military activities in Cambodia. Based on the twoprong test for congressional standing, it appears that the result in Mitchell was supportable and that the Holtzman court erred.

In challenging executive action alleged to encroach on the congressional war-making power, ${ }^{44}$ a congressman meets both prongs necessary to establish standing. First, he is able to allege injury to the performance of his job as a member of Congress.

tional amendment, see note 1 supra, the 20 plaintiff legislators alleged that their combined votes were sufficient to defeat ratification. Id. at 438. In congressional suits, the single congressman cannot claim with assurance that the executive action has defeated an opposing congressional majority. Thus, it might be argued that a congressman can bring an action only if authorized to do so by a majority resolution. Nonetheless, Coleman is important for the recognition it gives to the principle that legislators have cognizable interests, qua legislators, sufficient to allow standing to challenge acts which interfere with those interests.

${ }^{41}$ Notes 2-16 supra \& accompanying text.

42476 F.2d 533 (D.C. Cir. 1973).

43484 F.2d 1307 (2d Cir.), cert. denied, 94 S. Ct. 1935 (1974), rev'g Holtzman v. Richardson, 361 F. Supp. 544 (E.D.N.Y. 1973).

${ }^{44}$ See note 5 supra. 
The action taken by the executive is alleged to usurp powers granted in the Constitution solely to the legislative branch. Thus, the executive action challenged has a direct relationship to the congressman's duties and the usurpation constitutes the injury. The second step in establishing standing is similarly satisfied. The executive action is alleged to violate article I, section eight of the Constitution, which vests power to declare war in the legislative branch. This provision clearly was designed to protect congressional interests; the nexus between the plaintiffs' status as congressmen and the authority alleged to have been breached is thus established.

Yet despite the fact that the court of appeals in Mitchell and the district court in Holtzman reached the correct result, allowing the congressmen to sue, the reasoning in those cases was inadequate. In Mitchell, the court specifically rejected as a basis for standing the allegation of executive interference with the "plaintiffs' Constitutional right, as members of the Congress of the United States, to decide whether the United States should fight a war." 45 The court stated that article I, section eight does not give Congress the exclusive power to declare war, so that an executive breach of the constitutional language would not necessarily be a usurpation of a purely congressional right. ${ }^{46}$ The court recognized an implied exception, based on the necessities of modern warfare, to the Congress' power to declare war. ${ }^{47} \mathrm{~A}$ problem with this reasoning is that in any particular instance, executive action may exceed this narrow exception and violate congressional prerogatives. Congressmen should have standing to challenge such a violation; an allegation that the executive has waged war illegally thus necessarily supplies the needed nexus between congressional status and the nature of the infringement.

The court in Mitchell nonetheless relied on the following curious ground to grant standing:

If we, for the moment, assume that defendants' actions in continuing the hostilities in Indochina were or are beyond the authority conferred upon them by the Constitution, a declaration to that effect would bear upon the duties of plaintiffs to consider whether to impeach defendants, and upon plaintiffs' quite dis-

45476 F.2d at 536.

46 "[W]e are unanimously of the opinion that there are some types of war which, without Congressional approval, the President may begin to wage ...." Id.

${ }^{47}$ This implied exception should at the least be construed narrowly, in light of the explicit constitutional provision to the contrary. 
tinct and different duties to make appropriations to support the hostilities, or to take other legislative actions related to such hostilities, such as raising an army or enacting other civil or criminal legislation. ${ }^{48}$

The court thus implied that even absent an alleged usurpation of any congressional function, a congressman might have standing because a declaration of executive illegality would bear on the congressional duties of impeachment and authorization of appropriations. Thus, it would be unnecessary to establish either step in the test for congressional standing proposed above since the claimed illegality need have no relationship to Congress at all beyond other independent congressional powers. The reasoning used in Mitchell would essentially allow any congressional suit to challenge executive action since any act of the President or his subordinates could bear on appropriations. ${ }^{49}$ This result would be entirely inconsistent with the rationale of Sierra Club and its requirement of "injury in fact." 50

The court of appeals in Holtzman recognized the untenability of resting congressional standing on the tangential duties of Congress to impeach and to authorize appropriations. Indeed, the court noted that such a rationale amounts to "asking the judiciary for an advisory opinion which is precisely and historically what the 'cases and controversy' conditions set forth in Article III, Section 2 of the Constitution forbid." 51 The Holtzman court erred, however, in failing to note that an appropriate basis for congressional standing was the presence of allegations of executive interference with a congressional function, a basis recognized by the district court. ${ }^{52}$

The two-prong test for congressional standing was adopted by the district court in Kennedy $v$. Sampson, ${ }^{53}$ in which the plaintiff Senator was allowed to challenge a presidential poc-

48476 F.2d at 536.

49 Such a standard would allow congressional suits in all three of the hypothetical situations discussed in text accompanying notes 33-34 supra.

${ }^{50}$ See text accompanying note 31 supra.

51484 F.2d at 1315. See also H. Hart \& H. Wechsler, The Federal Courts AND THE Federal System 64-66 (2d ed. P. Bator, P. Mishkin, D. Shapiro \& H. Wechsler 1973).

52361 F. Supp. at 549. The lower court in Holtzman similarly relied on the unfortunate impeachment and appropriations language of Mitchell cited at text accompanying note 48 supra. The district courts in Kennedy v. Sampson, 364 F. Supp. 1075, 1079 (D.D.C. 1973) and Nader v. Bork, 366 F. Supp. 104, 106 (D.D.C. 1973) also cited the standing theory of Mitchell. 1974.

364 F. Supp. 1075 (D.D.C. 1973), aff'd, No. 73-2121, D.C. Cir., Aug. 14, 
ket veto. ${ }^{54}$ The court noted that the plaintiff had alleged that the pocket veto had impaired the effectiveness of his vote in favor of the bill and had deprived him of his right to vote to override the veto. ${ }^{55}$ Thus, the Senator had alleged injury sufficient to establish the appropriate nexus between his congressional status and the nature of action challenged.

Furthermore, the pocket veto was attacked as violative of article I, section seven of the Constitution. ${ }^{56}$ The interests to be protected by this provision certainly include the rights of congressmen to vote to override. Therefore, the Senator established the second nexus between his congressional status and the constitutional provision alleged to have been breached by the executive action. The Kennedy court, however, went beyond use of the two-prong test and cited as authority the Mitchell court's unpersuasive "impeachment and appropriations" basis for congressional standing.

The Mitchell reasoning might be considered unimportant dictum, since congressional standing was supportable on other grounds in each of the three cases discussed above. However, in Nader v. Bork, ${ }^{\mathbf{5 7}}$ the district court relied directly on Mitchell as authority for congressional standing to challenge the legality of the dismissal of Watergate Special Prosecutor Archibald Cox. ${ }^{58}$ The Nader result cannot be supported by use of the twoprong test. The plaintiff congressmen could not demonstrate a logical nexus between their congressional status and the dismissal of Cox so as to satisfy the first step. The dismissal did not in any way directly involve their duties as congressmen since Cox was not appointed by Congress and the dismissal could not properly be said to deprive the plaintiffs of any right to vote on any bills or even to pursue their own Watergate investigation. The court quoted a senator who presumably was at-

${ }^{54}$ See notes 6-8 supra \& accompanying text. The Family Practice of Medicine Act, S. 3418, 91st Cong., 2d Sess. (1970), had been sent to the President seven days prior to a five day congressional Christmas recess. The President refused to sign the bill and refused to return it to the Congress for a possible vote to override the veto, claiming that the adjournment allowed him to exercise a pocket veto.

${ }^{55} 364$ F. Supp. at 1078.

56 "Every Bill which shall have passed the House of Representatives and the Senate, shall, before it become a Law, be presented to the President of the United States; If he approve it he shall sign it, but if not he shall return it .... If any Bill shall not be returned by the President within ten days (Sundays excepted) after it shall have been presented to him, the Same shall be a Law, in like Manner as if he had signed it, unless the Congress by their Adjournment prevent its Return, in which Case it shall not be a Law."

${ }^{57} 366$ F. Supp. 104 (D.D.C. 1973), appeal docketed, No. 74-1260, D.C. Cir., Feb. 20, 1974. See note 8 supra \& accompanying text.

58366 F. Supp. at 106. 
tempting to demonstrate "injury in fact" as saying, "I am severely hampered in my ability to discharge my duties because of uncertainty which exists with respect to the legality of Special Prosecutor Cox's dismissal and the abolition of his office."59 But there is no reason to believe, under this rationale, that the senator had any interest in the outcome of the lawsuit other than a concern that the matter be resolved one way or another. ${ }^{60}$ Since the plaintiff congressmen are not seeking to vindicate a congressional right alleged to be directly impaired by the executive action, ${ }^{61}$ there is no reason to believe that they can present the issues with the necessary adverseness to ensure proper resolution of the issues. ${ }^{62}$ It is difficult to perceive how a determination of illegality of executive action would aid fulfillment of congressional duties any more than a determination of legality.

This consideration suggests the heart of the problem with relying on the tangential impeachment powers of Congress stressed in Mitchell. Without the unwarranted assumption that Congress has an affirmative interest in impeachment of the President (as opposed to mere vindication), there is no reason to believe that a congressman qua congressman has a sufficient connection to the controversy to allow standing. ${ }^{63}$ The resulting ease of congressional standing is inconsistent with the more stringent standing rules announced by the Supreme Court: ${ }^{64}$

\section{Standing for Congressmen as Representatives of the Public Interest}

The two-step test may seem adequate to provide a basis for congressional standing consistent with the leading Supreme

${ }^{59} I d$. at 106 n.2.

${ }^{60}$ Such a rationale could, of course, support congressional standing in any case whatever-even in a dispute between two private parties-since the outcome might bear on pending or future bills.

${ }^{61}$ The plaintiffs in Nader $v$. Bork alleged that the Cox dismissal was illegal on several bases. One ground was that at the time Elliot Richardson was confirmed as Attorney General by the Senate, assurances were given that Cox would be removable only for gross impropriety. Thus, it might be argued, on a contract basis that Congress had a direct interest in Cox's tenure. The district court correctly noted, however, that "[w] hatever may be the moral or political implications of the President's decision to disregard those commitments, they do not alter the fact that the commitments had no legal effect." $366 \mathrm{~F}$. Supp. at 109.

${ }^{62}$ See Sierra Club v. Morton, 405 U.S. 727, 731-32 (1972); Flast v. Cohen, 392 U.S. 83, 101 (1968); Baker v. Carr, 369 U.S. 186, 204 (1962). But see note 71 infra \& accompanying text.

${ }^{63} \mathrm{~A}$ possible basis for a congressional suit in situations where no congressional function is at issue might be the plaintiff's representation of the public interest. See section IV infra.

${ }^{64}$ See section I supra. 
Court cases and logically connected to the functions constitutionally assigned to congressmen. The test is not beyond criticism, however. One objection to the test is that it does not account for the fact that congressmen in these cases are not genuinely concerned with any real injury to themselves as such. Rather, they are motivated to seek judicial intervention out of concern for the public interest, a feeling that government should proceed according to law, or a generalized fear that excessive power in the executive branch has tipped the constitutional balance between the branches. If these concerns supply the genuine incentive for the lawsuits, it is questionable whether the proposed test sufficiently recognizes the underlying issues. Much like the criticism leveled at the Flast test for creating a legal fiction in recognizing taxpayer suits despite the trifling injury to taxpayers, ${ }^{65}$ one might suggest that the proposed test simply creates another legal fiction: that congressmen have some unique interest at stake other than as citizens concerned with good government. ${ }^{66}$

It is thus not unreasonable to contend that if standing is to be allowed in cases such as Mitchell $v$. Laird and Kennedy $v$. Sampson, it should be equally available in a case such as Nader v. Bork. ${ }^{67}$ The argument in favor of congressional standing in Nader, despite an inability to satisfy the two-step test, is strong. The central issue, the legality of the dismissal of the Special Watergate Prosecutor, was one of considerable public concern. ${ }^{68}$ Furthermore, the one undeniably suitable plaintiff, Cox himself, declined to seek judicial intervention for both personal and political reasons. ${ }^{69}$ Although there was no intrusion upon any purely congressional interests, ${ }^{70}$ there could be little question that the plaintiff congressmen were well-equipped to argue the illegality of the dismissal effectively and to present a position genuinely adverse, from the public interest viewpoint,

${ }^{65}$ Flast v. Cohen, 392 U.S. 83,116 (1968) (Harlan, J., dissenting); Bittker, The Case of the Fictitious Taxpayer: The Federal Taxpayer's Suit Twenty Years After Flast v. Cohen 36 U. CHr. L. REv. 364 (1969). Contra, Davis, The Case of the Real Taxpayer: A Reply to Professor Bittker, 36 U. CHI. L. Rev. 375 (1969). See also Davis, supra note 17, at 601 (trifling injury necessary and sufficient for standing).

${ }^{66}$ Justice Fortas suggested in Flast v. Cohen that the interest of a citizen qua citizen in enforcement of the Establishment Clause might have been adequate to allow standing. 392 U.S. at 115.

${ }^{67}$ See section III supra.

${ }^{68} 366$ F. Supp. 104, 106 (D.D.C. 1973).

${ }^{69} \mathrm{Cox}$, at the time of the suit, had announced his intention to return to Harvard Law School. N.Y. Times, Nov. 10, 1973, at 37, col. 3. He was also said to be reluctant to pursue the case for fear of being considered vindictive.

${ }^{70}$ Notes $60-62$ supra \& accompanying text. 
to that of the defendant. ${ }^{71}$ In short, the case was one in which it should have been within the discretion of the court to allow standing as it did. ${ }^{72}$

If one accepts this position, it becomes clear that the congressmen in these suits are not actually representing themselves, but rather are representing the public interest. The problem with so labeling these suits is that the Supreme Court has thus far refused to recognize the validity of the "public action."73 In Sierra Club, ${ }^{74}$ standing was denied a well-established environmental protection group for failure to allege any injury in fact to its members. As long as Sierra Club remains the law, satisfying the test will be the sine qua non for congressional standing.

There is good reason to believe that Sierra Club is not constitutionally compelled ${ }^{75}$ and that the Court may in time recognize suits for citizens representing the public interest. ${ }^{76}$ If such suits become available, congressmen should be able to challenge executive action not as congressmen but as representatives of the public interest. Since such suits are likely to be accepted, if at all, only in a court's discretion, ${ }^{77}$ the official position of the congressman will still be important since his role as a publicly-elected representative makes him an especially able plaintiff.

The arguments in favor of allowing public actions have been advanced persuasively by Professor Jaffe; ${ }^{78}$ some of his more important points bear reiteration here. He notes that there is considerable historical support for the public action. ${ }^{\mathbf{7 9}}$

${ }^{71}$ The political opposition of all three congressional plaintiffs to the President was well-established. Two had introduced resolutions of impeachment in the House of Representatives. 366 F. Supp. at 106 n.2. See text accompanying note 22 supra.

${ }^{72}$ Perhaps the court should not have dismissed Ralph Nader as plaintiff, on the same grounds. See note 85 infra.

${ }^{73}$ See L. Jaffe, Judicial Control of Administrative Action 459-500 (1965).

${ }^{74} 405$ U.S. 727 (1972). See note 31 supra \& accompanying text.

${ }^{75}$ For the view that a requirement of a personal stake is not a constitutional requirement inherent in article III "case" or "controversy," see Berger, supra note 20; Jaffe, supra note 20 , at 634 .

${ }^{76}$ There is currently a case before the Supreme Court in which the issue of citizen standing may well be definitively settled. Richardson v. Reservists Comm. to Stop the War, No. 73-1 188, granting cert. to Reservists Comm. to Stop the War v. Laird, No. 71-1535 (D. C. Cir., filed Oct. 31, 1972). See note 85 infra.

${ }^{77} \mathrm{See}$ Jaffe, supra note 20. For a discussion of the leading federal case which has allowed a "public action" and the factors which impelled the exercise of discretion in its favor, see note 85 infra.

${ }^{78}$ Professor Jaffe's arguments may be found in L. JAFre, supra note 73, at 459500 , and Jaffe, supra note 36.

${ }_{79}$ Professor Jaffe mentions the prerogative writ of mandamus and bill in equity for an injunction as well as certiorari, prohibition, and quo warranto as historical prototypes of "public actions." L. JAFFE, supra note 73, at 462. 
Furthermore, the two major arguments in favor of requiring a traditional plaintiff who has suffered direct injury are not persuasive. First, it has been argued that "injury in fact" is required to present the issues to the court properly. But, Jaffe notes, a lawsuit requires the expenditure of large sums of money, which indicates a desire to pursue the case vigorously. ${ }^{80}$ Second, Jaffe refutes the notion that requiring a traditional plaintiff is somehow more consonant with the underlying concepts of a democratic government since it limits judicial intervention to a minimum. ${ }^{81}$ Professor Jaffe concludes that "the character of the plaintiff and his claim for justice have very little relation to the kind of issue to be decided and the fitness of the judicial process for disposition of the issues" 82 and recommends the public action, in which a citizen represents the public interest, as a useful means of protecting minorities and individuals. ${ }^{83}$ Jaffe's advocacy of the public action has created considerable controversy ${ }^{84}$ and has thus far not been generally accepted by the courts. ${ }^{85}$ Congress could certainly settle the issue

${ }^{80} \mathrm{Jaffe}$, supra note 36 , at 1037-38.

${ }^{81}$ Id. $1038-40$.

${ }^{82}$ Id. 1040.

${ }^{83}$ Id. 1044-47.

${ }^{84}$ For views rejecting the public action, see Sierra Club v. Morton, 405 U.S. 727, 739-40 (1972); Flast v. Cohen, 392 U.S. 83, 116 (1968) (Harlan, J., dissenting); Davis, supra note 17.

${ }^{85}$ See Davis, supra note 17, at 614 ("[T] be made about the public action is that no federal court has ever allowed it.").

Since Professor Davis' statement, however, two federal courts have shown a willingness to allow citizen suits in certain circumstances. The leading case is Reservists Comm. to Stop the War v. Laird, 323 F. Supp. 833 (D.D.C. 1971), in which the plaintiffs challenged the rights of congressmen to hold a commission in the Armed Forces Reserves as a violation of article $I, \S 6$ of the Constitution. The Committee claimed standing on four bases: as reservists, injured by favoritism toward congressmen; as persons opposed to the Vietnam War; as taxpayers; and as citizens. Judge Gesell rejected all the proposed bases for standing except the last. After noting that "there are undoubtedly very few instances in which plaintiffs who assert merely the undifferentiated interest of citizens have a personal stake in the outcome sufficient to support standing," Judge Gesell cited four reasons for allowing the suit. First, no requirement of injury is necessary because the constitutional provision at issue seeks to avoid the "potential for undue influence rather than its realization." Second, "the issue tendered is a narrow one and involves a precise self-operative provision of the Constitution." Third, "the interest in maintaining independence among the branches of government is shared by all citizens equally." Finally, "the parties sharply conflict in both their interests and their views," thus avoiding "case" or "controversy" problems. Id. at 840-41.

The district court decision was affirmed without opinion, No. 71-1535 (D.C. Cir., filed Oct. 31, 1972) and the Supreme Court granted certiorari sub nom. Richardson v. Reservists Comm. to Stop the War, 411 U.S. 947 (1973) (No. 73-1188). Thus, the issue of citizen standing, albeit in a somewhat narrow context, should soon be decided.

It is interesting to note that Judge Gesell was the author of the opinion in Nader v. Bork. In Nader, he chose to allow standing not on the citizen basis of Reservists, but 
by passing legislation allowing citizens to bring lawsuits to vindicate the public interest in any situation or in those in which a court concludes that there is no other suitable plaintiff. ${ }^{86}$ If worried about a flood of such litigation, ${ }^{87}$ Congress could allow only lawsuits brought by congressmen as representatives of the public. However, in the absence of such legislation or any inclination of the courts to allow public actions, the two-step test discussed earlier remains the most useful basis for congressional standing to challenge intrusive executive action.

on the more questionable basis of impeachment powers stressed in Mitchell $v$. Laird. It would seem that Nader presents as strong a case for citizen standing as Reservists. See notes 67-72 supra \& accompanying text. Had Judge Gesell rested Nader on citizen standing, the dismissal of Ralph Nader as plaintiff would have been improper. Nader would seem as able to represent the public interest as are the three congressional plaintiffs, though one might argue that the congressmen, as publicly-elected representatives, are better able to protect citizen concerns.

Finally, Judge Lord, in a more recent decision, noted that the interests of a citizen-economic, governmental, and humanitarian-were sufficient to allow standing to challenge the constitutionality of the Vietnam War. Atlee v. Laird, 339 F. Supp. 1347, 1354-57 (E.D. Pa.), dismissed on other grounds, 347 F. Supp. 689 (E.D. Pa. 1972). This rationale would certainly support standing in Mitchell and Holtzman and might well be extended to apply to other cases as well.

${ }^{86}$ See Sierra Club v. Morton, 405 U.S. 727, 732 n.3 (1972). See also Clean Air Amendments of 1970, 42 U.S.C. $\$ 1857 \mathrm{~h}-2$ (1970) (authorizing suits by any citizen to enforce automobile emission standards). See note 85 supra.

${ }^{87}$ See Sierra Club v. Morton, 405 U.S. 727, 739-40 (1972). 